\title{
THE STOMACH AND ANAEMIA
}

\author{
George Discombe, M.D., B.Sc. \\ Pathologist, Central Middlesex Hospital, London, N.W. 10
}

The stomach's function is to prepare food for assimilation, and this may involve breakdown of large molecules, conversion of metallic ions into chelates, or combination of molecules found in food with some secreted by the stomach to form a more easily absorbed compound. The mechanical process of kneading the ingested food with the secretions must not be forgotten, though its importance may be exaggerated. Of these processes, the most important in the genesis of anaemia are the production of proteolytic enzymes to break down proteins, including those which form complexes with iron; the production of acid in concentration sufficient to maintain in solution this liberated iron, and the production of the intrinsic factor which combines with vitamin $B_{12}$ to render it absorbable. These secretory functions are reinforced by the storage and kneading functions, so that in a healthy stomach food is rapidly reduced to an almost homogeneous liquid which is squirted through into the duodenum whenever the stomach contracts.

One would therefore expect that any interference with these functions might contribute to the production of anaemia-an iron-deficiency anaemia should acid and enzymes be absent, a megaloblastic anaemia should intrinsic factor be deficient.

\section{Iatrogenic Deficiences}

The clearest evidence on these deficiencies can be obtained by studying patients whose stomachs have been removed. Unless some attempt has been made to reconstruct the storage component, as by the transplantation of a segment of colon into the place left by the stomach, the food passes straight into the small intestine, which is adapted not for kneading and mixing, but for the completion of digestion and absorption of its product. This failure of storage assures a rapid transit of food through the absorbing zone, so that absorption is likely to be imperfect. Even though in most patients digestion and absorption may appear adequate, when under stress the average, and even without stress the unusual patient, may fail to digest and absorb food in the needed quantity.
Such patients would be expected to suffer from multiple deficiencies. Total gastrectomy should lead to megaloblastic anaemia from intrinsic factor deficiency, and in fact, this usually develops three to five years after operation, about the time when the reserves built up in the liver before operation become exhausted. ${ }^{9}$ Lack of acid and pepsin would reduce the proportion of food iron brought into solution, and this, with rapid transit through the small intestine, reduces the absorption of both iron and protein. Partial gastrectomy, removing only the pyloric part of the stomach, leaves intact the area which secretes intrinsic factor so that among survivors from the operation, megaloblastic anaemia develops at the same rate as would be expected in any population of similar genetic constitution; Maclean ${ }^{42}$ considers that prospective sufferers can be detected at the time of operation, when histological examination of the body mucosa will show an atrophic gastritis.

Recently the iron deficiency which so often follows partial gastrectomy has been studied by Hobbs and Discombe ${ }^{31}$ and Hobbs, ${ }^{30}$ and, as might be expected, failure of absorption seems to be the principal factor, accounting for about two-thirds of the anaemia, as suggested by Hartfall $^{24}$ and Dedichen. ${ }^{16}$ It also appears that most patients after partial gastrectomy are in critical protein balance: ${ }^{37,49}$ in such cases response to iron therapy may depend on absorption of protein as much as on iron and Hobbs regards as excellent a rise in haemoglobin level of $2 \mathrm{~g}$. in a month-i.e., about $\frac{1}{2} \%$ daily, compared with figures of $1 \%$ to $3 \%$ daily which can be obtained in simple iron deficiency occurring in well nourished patients; he points out that little increase over these rates is obtained even when parenteral iron is administered. Owren ${ }^{48}$ showed that in such cases tablets could pass from mouth to colon in about 20 mins. were the patient standing, but disintegrated within the absorbing area if the patient lay down; the importance of posture has further been emphasized by Goldeck and Gudermann $^{23}$ and Hobbs. ${ }^{30}$

So much for the iatrogenic anaemias involving 
the stomach; they are now easily treated, and patients need no longer suffer chronic sideropenia, which causes so much lassitude, lack of energy, and loss of weight after partial gastrectomy, and plays some part in the genesis of the dumping syndrome. $^{2}, 24,26,27,33,47,50,51,60$

\section{Natural Disorders of the Stomach}

There are diseases which may involve the stomach accidentally, or because the stomach is a natural seat of the disease, though it may also manifest elsewhere. Some of these produce anaemia by causing bleeding, and of these the chief is peptic ulceration, which produces anaemia not by interference with normal secretion, but by causing loss of blood, which, when it averages $6 \mathrm{ml}$. daily in a man, or less in a woman, usually causes a negative iron balance. Most iron deficiency in men, and much of that in women, can be traced to chronic bleeding from a peptic ulcer, usually punctuated by episodes of more serious bleeding which are sometimes, but not always, recognized as haematemesis or melaena. It is worth noting that this $6 \mathrm{ml}$. daily is quite close to the critical level for the detection of occult blood in stools by the usual tests (about $\mathrm{r}$ to $3 \mathrm{ml}$.), so that if, as is usually the case, blood loss varies from day to day, it may not always be detected, so that in suspicious cases many tests must be done before a negative result can be accepted. Bleeding from acute ulceration is, fortunately, less common, for it tends to be torrential from the start. Other causes of bleeding may be sought in the gastro-enterological texts. ${ }^{1}$

\section{Disorders of the Gastric Secretions}

These might involve any or all of acid production, enzyme production, and intrinsic factor production; and they might be either primary or secondary to some other lesion. It is, for example, clear that iron deficiency anaemia in young people may be associated with achlorhydria, but that normal secretion of acid sometimes returns when the deficiency is corrected, ${ }^{7,41}$ though this did not occur in the patients of Lees and Rosenthal..$^{39}$ Superficial gastritis is much commoner in patients with iron deficiency than in normal controls, but is not always accompanied by achlorhydria. ${ }^{13}$ If we exclude the consequences of recovery after a corrosive poison, the only lesion which produces complete absence of all these secretions seems to be that which leads ultimately to pernicious anaemia; a process which continues over many years, perhaps most of the patient's life, to its final stage, a degeneration of the body mucosa to a state in which it is not to be distinguished, from the simplest mucosa of the small intestine full of goblet cells; coincidentally

the muscular components of the stomach become atrophic. ${ }^{17}, 21,35,43,63$

In 1930, Magnus and Ungley ${ }^{44}$ concluded thato pernicious anaemia was invariably associated with gastric atrophy. In 1955, however', Joske, Finkh. and Wood ${ }^{35}$ showed that in about $60 \%$ of cases of clinically typical pernicious anaemia, there waso present an inflammatory atrophic gastritis witho survival of body chief and oxyntic cells; and $\bar{c}$ Robertson, Wood and Joske ${ }^{53}$ record the develop- $\mathbb{8}$ ment of pernicious anaemia in a man not lesso than five years after he was found to have complete gastric atrophy.

The Oxford school, trying to assess gastric $\vec{\omega}$ secretion, have encountered similar anomalies. Retief $^{52}$ showed that of the patients who secreteo no free acid in Kay's ${ }^{36}$ augmented histamine test 3 . meal, about half have subnormal vitamin $B_{12} \omega$ absorption; Callender and Denborough ${ }^{8}$ studied the relatives of patients with pernicious anaema N and found many with achlorhydria and lowered $\infty$ serum vitamin $B_{12}$ levels, but without overt ${ }^{\omega}$ disease. During the period of progressive atrophy the secretions continue to diminish, though very $\vec{\square}$ slowly-volume, acid, pepsin, intrinsic factorbut they may not all diminish at the same rate; $\mathbb{\complement}$ there is a little evidence which suggests that $\overline{0}$ reduction in acid secretion may precede the others, and that, as first suggested by Faber, ${ }^{20}$ in son $\vec{\circ}$ cases loss of intrinsic factor may occur befor there is any histologically recognizable abnormalif in the body mucosa. ${ }^{45}$

\section{Hypovitaminosis $B_{12}$}

We now know that vitamin $B_{12}$ is necessary for $\stackrel{\unrhd}{\varrho}$ the continued well-being of many cells. Not $\overrightarrow{\overrightarrow{0}}$ only are erythroblasts and immature granulocytes affected by its absence, but also the oral epithelium and some neural cells, particularly those mediating protopathic sensation (sub-acute combined degeneration) and those in the central area of the retina, for tobacco amblyopia can be the presenting symptom of pernicious anaemia. ${ }^{25,40}$ Some degree of mental deterioration is usual and $\frac{\rho}{3}$ psychoses are not rare. ${ }^{22}$

We should therefore cease to regard pernicious anaemia as a disease entity, ${ }^{12}$ and consider it as a $\frac{\overrightarrow{0}}{2}$ symptomatic epiphenomenon of hypovitaminosis $\mathrm{B}_{12}$ induced by a progressive gastric atrophy; the $\widetilde{N}$ hypovitaminosis can be completely asymptomatic, N or it may affect any or all of certain tissues, thus $\stackrel{\sim}{\mathrm{N}}$ producing symptoms.

Tissue Affected Oral epithelium
Symptom Complex Glossitis, in early stage red $\mathbb{Ð}$ and inflammatory later? atrophic. 
Tissue Affected Retina.

Afferent sensory nerves

Cerebral hemispheres

Bone-marrow

Symptoms are not necessarily produced as soon as vitamin $B_{12}$ stores are depleted or exhausted; a few patients with very low serum vitamin $B_{12}$ levels, but without anaemia or any other lesions attributable to hypovitaminosis $B_{12}$, have been encountered..$^{38,46}$ We do not know what other factors are needed to produce symptoms, but we do know that glossitis, sub-acute combined degeneration of the spinal cord, ${ }^{34}$ degeneration of the retina, ${ }^{25}$ and gross psychological disturbances, ${ }^{22}$ and combinations of these ${ }^{6}$ can develop in the complete absence of anaemia or of megaloblastic change.

\section{The Genesis of Gastric Atrophy}

This progressive gastric atrophy seems to be inborn and genetically controlled. The mode of inheritance is not yet certain, but it may be as a unit character-difference with fairly complete single-dose expression (Mendelian dominant) masked clinically by early death or by failure to develop the usual clinical consequence of malabsorption of vitamin $\mathrm{B}_{12}$-that is, megaloblastic anaemia. The genetic factor is very much more common in North Europeans than in other ethnic groups, and in general, the further north you go and the less sun you see, the commoner is pernicious anaemia; in Great Britain the incidence varies between 0.6 in the south to 2.46 per 1,000 in the north, ${ }^{56}$ and estimates of the causative atrophic gastritis range between $0.5 \%$ of all women, $1 \%$ of all normal adults, and $5 \%$ of all people over $40 .^{63}$ In Austria or Italy the disease is much less common; in Spain rare; in Central Africans so rare that only about five cases have been recorded ${ }^{14}$ and it is almost unknown among those of Mongolian race.

The mechanism of this progressive atrophy is completely unknown; it is interesting to note that in a case of ' juvenile' pernicious anaemia, though there was a complete absence of intrinsic factor, the body mucosa was histologically normal and normal secretion of acid and pepsin occurred, ${ }^{45}$ so it is possible that some failure of production may occur at an early age. A few people, basing their views on the observation that the serum of patients with pernicious anaemia inhibits the activity of intrinsic factor, ${ }^{58}$ suggest that the lesion may be due to auto-antibodies, acting on the intrinsic factor itself or on the cells which secrete it.

\section{The Relationship of Simple Achlorhydric Anaemia to Pernicious Anaemia}

In the course of this progressive atrophy, iron deficiency often appears, especially when the patient is a woman who loses blood regularly and sometimes excessively; reduction in the secretion of acid and enzymes renders the absorption of iron less satisfactory. The clinical pattern of this iron deficiency is characteristic; the patient is in the fourth or fifth decade of life, and has usually grey hair, a smooth tongue sometimes sore, often cracks at the corners of the mouth, and complains of dyspepsia and lack of appetite. Occasionally there is true dysphagia with a pharyngeal web (Plummer-Vinson or Patterson-Kelly syndrome). Paraesthesiae are common.

This syndrome constitutes the idiopathic hypochromic anaemia of Faber ${ }^{18,19}$ and Witts ${ }^{61,62}$ in its most severe form. Davies ${ }^{14}, 15$ studied the gastric lesion in such cases, and was able to demonstrate all degrees of secretory failure, suggesting that many cases of idiopathic hypochromic anaemia will progress to pernicious anaemia if they live long enough-and most haematologists can find among their own patients some who illustrate this progress. There is little doubt that idiopathic hypochromic anaemia in its classical form is a stage in the development of hypovitaminosis $B_{12}$ in the anaemic form (i.e. pernicious anaemia), though it is an inconstant stage whose appearance probably depends on the time when achlorhydria develops, on the relation between disappearance of acid and intrinsic factor from the gastric secretion, and, above all, on the occurrence of excessive menstrual bleeding and on the time of the menopause; if gastric atrophy develops so slowly that the menopause is past before achlorhydria is complete, then one would expect to see pernicious anaemia without coincidental iron deficiency, just as one would if the iron deficiency had been adequately treated. For similar reasons one would expect the age of onset of pernicious anaemia to vary widely, and in fact, though occasional cases may appear before the age of 40 , it becomes commoner with advancing age, especially in women, possibly because women live longer and so give the disease a better chance to manifest. ${ }^{13}$

\section{Achlorhydria and Iron Absorption}

Genuine achlorhydria, that is, achlorhydria which persists even when large doses of histamine, covered by an anti-histamine drug, are adminis- 


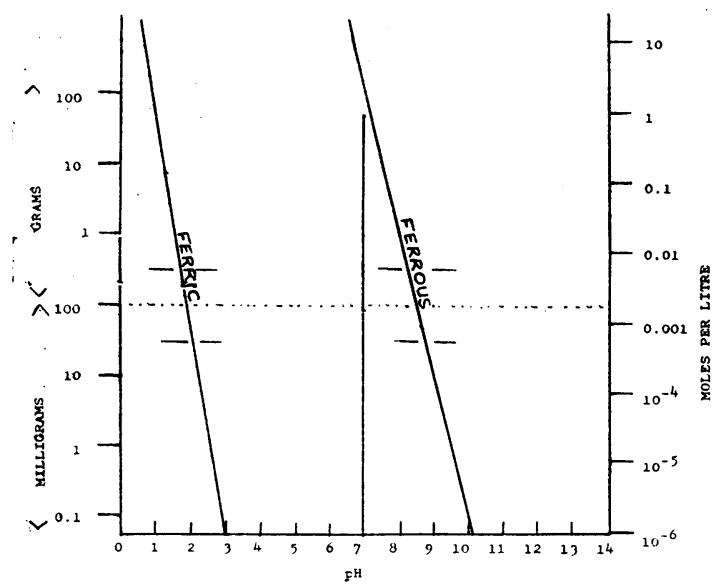

FIG. 1.-Concentration of ferric and ferrous ions present in aqueous solutions of different $\mathrm{pH}$. Abscissa$\mathrm{pH}$; ordinate - concentration of iron ions (expressed as moles per litre on the right and as grammes or milligrammes per litre on the left).

The dotted horizontal line is at a concentration of $100 \mathrm{mg}$. per litre: the bars above and below at 300 and $30 \mathrm{mg}$. per litre indicate the probable range encountered in practice.

Vertical line at $\mathrm{pH} 7$, the neutral point.

Note.-Vertical scales are logarithmic.

tered, is so rare that it has been thought to occur only in patients with pernicious anaemia and in those who are fated to develop it. ${ }^{10}$ The association of severe hypochlorhydria with iron deficiency is probably due to two factors: first, lack of acid and pepsin delay the digestion of food iron, much of which is combined with protein as ferritin and haemosiderin; and second, most food iron is in the ferric state which is almost completely insoluble at $\mathrm{pH}_{3}$ or more, a degree of acidity never exceeded in the achlorhydric stomach. Further, even powerful reducing substances find it difficult to reduce ferric iron, insoluble and complexed with protein, to the much more soluble ferrous iron (Fig. I). Medicinal iron, especially if initially in the ferrous state and maintained thus with large doses of reducing agent, remains dissolved even at $\mathrm{pH}$ levels as alkaline as $\mathrm{pH} 8$.

However, there are plenty of cases of iron deficiency without gastric atrophy, and even without hypochlorhydria. Nine patients out of ten with iron deficiency are anaemic because they have been bleeding, and these patients usually have a fairly normal gastric mucosa; even among elderly women iron deficiency without gastric atrophy is more common than is anaemia with gastric atrophy, and their stomatitis is as likely to be due to deficiency of riboflavin or other $B$ vitamins as to vitamin $B_{12}$ deficiency. It must be remembered that the age of onset of simple achlorhydric anaemia (perhaps, more correctly, sideropenic pre-megaloblastic hypovitaminosis- $\mathrm{B}_{1 \mathrm{~m}}$ -Domine defende nos!) is the same as that of simple iron deficiency due to menopausal dis turbances of menstruation, and that the oral and gastro-intestinal symptoms accompanying it are probably manifestations of deficiency of gastrie secretion and of vitamin $B_{12}$ thrown into promis nence by the stress of iron deficiency.

\section{The Effect of Iron Deficiency}

The days are past when we could believe tha娄 the only significant effect of iron deficiency was to produce anaemia; the occurrence of koilonychia, cheilosis and digestive disturbances, and the sub $\vec{\omega}$ jective sensations of lassitude and tiredness, often with palpitations, all suggest that other mechano isms may be involved, the more so because eve minor degrees of iron deficiency seem to cause complaints out of proportion to their severity代 My first proof of this was when a mild attack of the bloody flux caused a male colleague to developo koilonychia without anaemia or evidence of iron deficiency among the red cells, and I was able to cure this by injecting only $240 \mathrm{mg}$. iron; soon afterwards Reimann ${ }^{50}$ showed that chronic irom deficiency in infancy and childhood affected the rate of growth and the development of sexuras characteristics; Waldenstrom, ${ }^{60}$ Jasinski, ${ }^{32}$ and Henderson $^{29}$ have shown that sideropenia sine anaemia (masked sideropenia) gives rise to complex of symptoms differing only slightly fromi those of gross iron deficiency anaemia, and Hobb\$ has found that it is involved in the maintenance of weight after partial gastrectomy. Beutler and his colleagues ${ }^{3}$ have shown that sideropenia is accompanied by tissue enzyme deficiencies, an\&

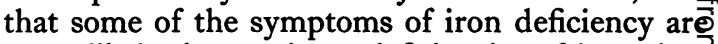
more likely due to tissue deficiencies of iron than to the anaemic. 4

\section{Conclusion}

What, then, are the practical consequences of this alteration in our attitude to pernicious anaemia, to this widening of our horizon which shows us that anaemia is only one of manæ̋ possible consequences of a progressive atrophic gastritis ? First, we shall have to review many patients with neurological disorders or confusiona states which might conceivably be ascribed t $\overline{-}$. hypovitaminosis- $\mathrm{B}_{12}$, and since anaemia may bo absent, this investigation must involve either an augmented histamine test meal, determination of the absorption of radioactive vitamin $\mathrm{B}_{12}$, a gastrif biopsy, or a determination of the serum vitamin $B_{12}$ level. Of these, only the last is practicable on a large scale, and the proportion of positives is likely to be small, if Sewell's (private communication) preliminary results are any guide; how 
ever, if the deficiency is missed the patient usually suffers greatly, so it seems that the estimation of serum vitamin $B_{12}$ will soon become an essential part of the investigation of the patient with the more obscure neurological disorders.

It could be argued that a therapeutic test would suffice, but this is hardly wise in the more chronic disorders in which improvement appears to be little more than an arrest of progress.

\section{Treatment}

The treatment of hypovitaminosis $B_{12}$ is fortunately simple and cheap; it consists in the regular injection of adequate quantities of the pure vitamin. Each individual dose should be fairly small, for much of a large dose is excreted in the urine; initially, half a dozen to a dozen injections each of $200 \mu \mathrm{g}$. spread over a fortnight or a month will not merely relieve the symptoms and most of the signs, but leave stores for several months deposited in the liver; thereafter $200 \mu \mathrm{g}$. every three or four weeks should suffice.

There is no justification for treating the ordinary patient with oral preparations. It is true that daily oral administration of $100 \mu \mathrm{g}$. or more of the pure vitamin will in most cases produce adequate response and even normal blood levels, ${ }^{11,28}$ but there are many patients who respond less satisfactorily and inadequately treated patients may develop severe neurological disturbances. The much recommended compounds of vitamin $B_{12}$ with hog gastric mucosa or intrinsic factor (Bifacton, Cycloplex) should never be used, for many patients treated with them become refractory to these preparations and relapse even though taking large doses, ${ }^{5,38,54,55,57}$ and the vitamin $B_{12}$-peptide complex of Heathcote and Mooney has been found by some to produce sub-optimal levels of vitamin $B_{12}$ in the serum. ${ }^{59}$

In any case, regular visits to the doctor for an injection give the patient a chance of consultations at regular intervals, and it is quite possible that these regular consultations give the patient a better chance of prolonged survival than those for whom such a consultation is an important event - for patients with pernicious anaemia are all middle-aged or elderly, and simple medical advice may be very useful.

\section{REFERENCES}

I. AVERY JONES, F., and GUMMER, J. W. P. (1960), ' Clinical Gastroenterology '. Oxford: Blackwell.

2. BEUTLER, E. (1957), Amer. F. med. Sci., 234, 517.

3. BEUTLER, E., and BLAISDELL, R. K. (1960), Blood, 15, 30.

4. BEUTLER, E., LARSH, S., and GURNEY, C. W. (1959), F. Lab. clin. Med., 54, 791.

5. BLACKBURN, E. K., SPRAY, G. H., SWAN, H. T., TUDHOPE, G. R., and WILSON, G. M. (1959), Brit. med. J., i, 535 .

6. BOEN, S. T., MOLHUYSEN, J. A., and STEENBERGEN, J. (1958), Lancet, ii, 294.
7. BRUMFITT, W. (1960), Quart. F. Med. N.S., 29, I.

8. CALLENDER, S. T., and DENBOROUGH, M.A. (1957), Brit. F. Haemat., 3, 88 .

9. CALLENDER, S. T., TURNBULL, A., and WAKISAKA, G. (1954), Clin. Sci., 13, 221.

10. CARD, W. I., MARKS, I. N., and SIRCUS, W. (1955), F. Physiol. (Lond.), 130, 18P.

I I. CHALMERS, J. N. M., and SHINTON, N. K. (1958), Lancet. ii, 1298.

12. DAVIDSON, SIR S. (1957), Brit. med. f., i, 24 I.

13. DAVIDSON, W. M. B., and MARKSON, J. L. (1955), Lancet, ii, 639.

14. DAVIES, D. T. (1931), Ibid., ii, 385.

15. DAVIES, D. T. (1931), Quart. F. Med., 24, 447.

16. DEDICHEN, J. (1934), Acta chir. scand., 75, 242.

17. DOIG, R. K., and WOOD, I. G. (1950), Med. F. Aust., 2, 565.

18. FABER, K. (1909), Med. Klin., 5, 1313.

19. FABER, K. (1913), Klin. Wschr., 50, 958.

20. FABER, K. (1926), Amer. Y. med. Sci., 172, 1.

21. FLINT, A. (1860), Amer. med. Times, 1, 181.

22. FRASER, T. (1960), Lancet, ii, 458.

23. GOLDECK, H., and GUDERMANN, E. (1954), Artzl. Wschr., 9, 39.

24. HARTFALL, S. J. (1934), Brit. med. F., i, 136.

25. HEATON, J. M., MvCORMICK, A. J. A., and FREEMAN, A. G. (1958), Lancet, ii, 286.

26. HEINRICH, G. (1954), Dtsch. med. F., 5, 60.

27. HEINRICH, G. (1954), Artzl. Wschr., 8, 432.

28. HEMSTED, E. G., and MILLS, J. (1958), Lanret, ii, 1302.

29. HENDERSON, I. D. (1954), Ibid., i, 493.

30. HOBBS, J. R. (196r), Gut (to appear).

31. HOBBS, J. R., and DISCOMBE, G. (1961), Proc. 7th Cong. Europ. Soc. Haemat. Lond., 1959, part 2, p. 101.

32. JASINSKI, B. (1949), Schweiz. med. Wschr., 79, 1255.

33. JASINSKI, B., and OTT, W. (195I), Ibid., 81, 1141 .

34. JEWESBURY, E. C. O. (1954), Lancet, ii, 307.

35. JOSKE, R. A., FINKH, E. S., and WOOD, I. J. (1955), Quart. f. Med., 24, 269.

36. KAY, A. W. (1953), Brit. med. F., ii, 77.

37. KENNEDY-WYATT, J., WALKER, R. S., and MONRO, J. I. (1960), Ibid., i, 320 .

38. KRISTENSEN, H. P. O S., LUND, J., SOENBORG OHLSEN, A., and PEDERSEN, J. (1957), Lancet, i, 1266. 39. LEES, F., and ROSENTHAL, F. D. (1958), Quart. F. Med.
N.S., 27, I9.

40. LEISHMAN, R. (1952), Trans. ophthal. Soc. U.K., 7I, 319.

41. LEONARD, B. J. (1954), Lancet, i, 899.

42. MACLEAN, L. D. (1957), New Eng. F. Med., 257, 262.

43. MAGNUS, H. A. (1960), Proc. 7 th Cong. europ. Soc. Haemat. Lond., 1959. Acta haemat. (Basel), 24, 6.

44. MAGNUS, H. A., and UNGLEY, C. C. (1938), Lancet, i, 420. 45. MOLLIN, D. L., BAKER, S. S., and DONIACH, I. (1955), Brit. F. Haemat., $\mathrm{x}, 278$.

46. MOLLIN, D. L., BOOTH, C. C., and BAKER, S. J. (1957), Ibid., 3, 412.

47. OTT, W., and JASINSKI, B. (1954), Gastroenterologia (Basel), 82, 14.

48. OWREN, P. A. (1952), Acta chir. scand., 104, 206.

49. PATTARIN, L. (1958), Arch. ital. Mal. Appar. dig., 24, 187.

50. REIMANN, F. (1956), Demonstration Int. Soc. Haemat., Boston.

51. REMY, D., GOLDECK, H., and PANTELMANN, H. A (1953), Z. klin. Med., 150, 455.

52. RETIEF, F. P. (1959), Acta haemat. (Basel), 24, I.

53. ROBERTSON, E. G., WOOD, I. J., and JOSKE, R. A. (1955), Lancet, ii, 69 .

54. SCHWARTZ, M., LOUS, P., and MEULENGRACHT, E. (1957), Ibid., i, 75 I.

55. SCH $\backslash$ ARTZ, M., LOUS, P., and MEULENGRACHT, E. (1958), Ibid., ii, 1200.

56. SCOTT, E. (1960), F. Coll. Gen. Pract., 3, 80.

57. STOKES, J. B., and PITNEY, W. R. (1958), Lancet, i, 322.

58. TAYLOR, K. B. (1959), Ibid., ii, 106.

59. VARADI, S. (1959), Brit. med. f., ii, 756.

60. WALDENSTROM, J. (1938), Acta med. scand., Suppl., 90, 380. 6r. WITTS, L. J. (1930), Guy's Hosp. Rep., 80, 253.

62. WITTS, L. J. (193I), Brit. med. f., ii, 883 .

63. WITTS, L. J. (1960), Acta haemat. (Basel), 24, 1.

64. WOODS, J. D., and RYMER, J. J.H. (1955), Lancet, ii, 1274 